\title{
Analysis of the Effectiveness of MPBH: The Mains of Mandai as a Saving Food in Banjarmasin Community
}

\author{
Mohamad Zaenal Arifin Anis ${ }^{1 *}$ Heri Susanto ${ }^{1}$ Sriwati $^{1}$ Fitri Mardiani ${ }^{1}$ \\ ${ }^{1}$ Faculty of Teacher Training and Education, Lambung Mangkurat University, Banjarmasin, Indonesia \\ ${ }^{*}$ Corresponding author.Email:mzarifinanis@ulm.ac.id
}

\begin{abstract}
The widespread use of models in learning history in modern countries has affected education in Indonesia. One of them is by imitating and even being obliged to follow this trend in the learning process in the classroom without paying attention to the social and cultural backgrounds of students. However, in reality the use of these models does not make the learning process run smoothly as imagined and expected. Although there have been many studies conducted by educators and observers of education which state that the use of models in history learning is very effective in building a more meaningful learning atmosphere. The purpose of this study is to analyze the effectiveness of the Historical Thinking Learning Model (MPBH) in order to shape students' understanding of the subject of mandai as a savior food in Banjarmasin society. The subjects to be studied are students who are participants in the social history course. The research findings show that learning through MPBH encourages students to understand the past, unravel parts of historical stories, and find their meaning to practice developing thinking skills. So that learning history is able to develop thinking that emphasizes scientific principles. Therefore, the MPBH is very effective in colliding academic behavior against student academic culture in studying social history on this subject. The subjects to be studied are students who are participants in the social history course. The research findings show that learning through MPBH encourages students to understand the past, unravel parts of historical stories, and find their meaning to practice developing thinking skills. So that learning history is able to develop thinking that emphasizes scientific principles. Therefore, the MPBH is very effective in colliding academic behavior against student academic culture in studying social history on this subject. The subjects to be studied are students who are participants in the social history course. The research findings show that learning through MPBH encourages students to understand the past, unravel parts of historical stories, and find their meaning to practice developing thinking skills. So that learning history is able to develop thinking that emphasizes scientific principles. Therefore, MPBH is very effective in colliding academic behavior against student academic culture in studying social history on this subject. and find its meaning to practice developing thinking skills. So that learning history is able to develop thinking that emphasizes scientific principles. Therefore, the MPBH is very effective in colliding academic behavior against student academic culture in studying social history on this subject. and find its meaning to practice developing thinking skills. So that learning history is able to develop thinking that emphasizes scientific principles. Therefore, MPBH is very effective in colliding academic behavior against student academic culture in studying social history on this subject.
\end{abstract}

Keywords: MPBH, effectiveness, culture, mandai, and Banjarmasin society.

\section{INTRODUCTION}

Various innovations in education seem to prevent Indonesia from being left behind by other countries. Including the use of learning models both cooperative and collaborative. The application of models in learning history is a must so that learners are motivated to think critically which will also have a positive impact on learning outcomes. Learning history critically must be based on historical thinking. So that one important aspect of learning history is the ability to think historically [1].

Many teachers have chosen the appropriate models for learning history as an alternative in determining their teaching strategies. There are several learning models that are suitable for learning critical history, one of which is the Investigation Group (GI) model. The GI model in its application is able to build learning towards critical thinking through cooperative activities. Likewise with the Research Exercise model which allows students to look for historical facts independently to get scientific truth using historical methods [2]. However, if we look closely, the GI model and the Research Exercise when applied in historical learning implicitly do not show a postmodern approach that deconstructs the collective memory approach. The most important thing is the concept of historical continuity so that 
students can relate actual events to historical phenomena. Research on historical thinking has been done a lot including finding evaluation models but rarely discussing the content and atmosphere of learning qualitatively.

To build the ability to think history in learning, a learning model is needed. Therefore, the Historical Thinking Learning Model (MPBH) was built so that students can look for relationships between current events and historical phenomena [3]. In this case, the topic of mandai is chosen as a savior food in Banjarmasin society. The implementation of MPBH was initially considered difficult because students tended to understand that history was a past event where only mono causality occurred, the year of the incident, and the names of the elite, while the role of ordinary people did not appear, so history was not democratic.

However, based on the results of research conducted by the team, the application of the MPBH in history learning is considered effective for this subject. If we look closely, so far the results of research on the effectiveness of MPBH are only based on the results of the $t$ test, not yet analyzed qualitatively. Therefore, in order to fill the gap, the qualitative analysis of the effectiveness of MPBH is considered important so that the empirical data on MPBH is more filled. In this case, several factors that became the spotlight of researchers, including the behavior and academic culture of students, also contributed sufficiently to see the adaptation of learning innovations.

\section{LITERATURE REVIEW}

Learning objectives can be carried out well if in learning the lecturer can choose an approach, strategy, method or learning model which of course leads to the condition of the students, the abilities of the students, and the characteristics of the students. Choosing the right learning approach is very important for lecturers, however, each lecturer has different teaching styles even though they use learning approaches, methods or models. Progress exposes the Indonesian people to the impacts of globalization and developments in science and technology, as well as shifting values. education must be the leading sector. There is a belief that education must be a pioneer in overcoming various problems of the nation today [4].

Today's education requires innovation and a learning revolution in accordance with advances in science and technology without neglecting human values. Education is also seen as a means of giving birth to intelligent, creative, skilled, responsible, productive, and virtuous people [5]. In accordance with what was described by Brian Gravey and Mary Krug in historical learning models, it was written that learning history is learning that increases the output and character values of students and refers to strengthening the analogies and explanations of students, especially if it is associated with the theme of the discussion. thematicscientific [6]. Peter [7] says about history educators must work with a model of historical thinking if they are to formulate potential progression in students' advance through a school history curriculum, test that progression empirically, and shape instructional experiences in order to maximize that progression" .Learning history is a door to learn and discover lessons about what happened. Learning history is learning about humanity in all its aspects, because it will give birth to awareness about the nature of human culture and civilization development [8]. Isjoni [9] said that History is a lesson that imparts knowledge and values regarding the process of change and development of Indonesian society and the world in the past to the present. Thus history is an important aspect to be taught to students. According to Wasino, the history learning activity requires a medium to develop a sense of concern and interest in their regional realm, to further explore what has been in the past trajectory in the region [10].

Food, from a socio-cultural perspective, has a broader meaning than just a source of nutrition. Associated with trust, status, prestige, solidarity and peace [11]. Food will not have any meaning unless food is seen in its culture or social interaction network [12].

Mandai Cempedak is a popular local food for the people of South Kalimantan. This traditional fermented product can be found almost every time. The traditional fermentation of mandai cempedak has been around for a long time, in particular, this food has become one of the favorite foods which is considered as a savior food for the banjar community at critical times. Fermented mandai cempedak can be stored for a long time, namely 1-2 years [13]. Mandai is a type of traditional food made by fermentation with high salt content [14]. Therefore, this food can be used as a mainstay and is said to be a savior food for the banjar community because it can provide benefits when difficult circumstances occur.

Historical thinking is an attempt by historians to think about issues and place historical events in context and time sequence (chronology) by considering different perspectives of events by taking the bias and content of various selected documents [15]. Historical thinking is a continuous activity, in which there are activities of reading, writing, linking material with one another, and analyzing the material obtained such as how to compare historical events with one another, why historical events occur and how they impact [16]. the ability to think history (historical thinking) leads to active students and is able to improve learning outcomes and can make it easier for students to understand material, especially in history lessons. Through the ability to think historically prepares students to develop abilities and readiness to face various information that is already available [17]. The Historical Thinking Learning Model (MPBH) is an alternative to linking contemporary social issues with selected historical problems, is critical of sources and builds student creativity to find solutions. MPBH is based on the educational philosophy of constructivism which begins with the cognitiveism of Piaget and Vygotsky's thinking. Cognitive leads to learning as an activity of assimilation and accommodation of controlled external activities [18]. According to Seixas, historical thinking skills are divided into six types, namely: a) Skills to build historical meaning; b) Skills in using primary sources and historical evidence; c) Skills to identify continuity and change; d) Skills to analyze cause and effect; e) Information retrieval skills; f) Skills to understand ethical 
dimensions and historical interpretation [19]. d) Skills to analyze cause and effect; e) Information retrieval skills; f) Skills to understand ethical dimensions and historical interpretation [19]. d) Skills to analyze cause and effect; e) Information retrieval skills; f) Skills to understand ethical dimensions and historical interpretation [19].

Learning style is a tendency or the way students absorb and communicate information effectively which is represented in speech patterns, learning methods, how to do assignments, how to respond to other people, and other preferred activities [20]. Learning style is one of the internal factors that affect student achievement. Every learning activity, of course, always hopes to produce maximum learning [21]. Learning culture indicators consisting of the influence of the environment (or environmental conditions), practice, and habits, are in good condition (or learning culture is in good condition), so it can be assumed that learning outcomes will be good too. Likewise, if the indicators are in a bad condition, it can be assumed that learning outcomes will also be bad. Thus, learning culture has an effect on learning outcomes, with a positive influence pattern [22].

\section{METHODOLOGY}

This research uses a qualitative approach. Carry out a deeper analysis by narrating the results of the effectiveness of the historical thinking learning model carried out by the development team in previous studies. to obtain information and facts that are used to analyze the effectiveness and understanding of the subject being studied. The informant is a student of the History Education Study Program of the Teaching and Education Faculty (FKIP), Lambung Mangkurat University. There were 53 participants in the social history course plus 3 lecturers.

Researchers are lecturers of the History Education Study Program (FKIP) who have access to faculties, study programs, and of course students. Interviews and observations lasted for 2 semesters (one year). Observations were made during the learning process in the classroom, while interviews were conducted outside lecture hours when students as research subjects agreed to be interviewed as research subjects. The background of the subjects in this study were students who were ethnic Banjar. Generally, they come from the Hulu Sungai area with their socioeconomic background being in the middle to lower level.

In addition, for the people of the upstream area, mandai is a favorite food that most of them must have at home. When the season for cempedak fruit arrives, besides being made as emergency food during times of economic hardship, this food will also be traded to increase income for them.

This is one of the highlights in the socio-cultural history of the banjar community. Seeing mandai as a "food embedding" this research will also highlight how the longexisting learning culture will work with a developed learning model such as MPBH.

The facts obtained are research findings based on data from interviews, observations and documentation regarding motivation, criticality in exploring sources, development of knowledge, responses, achievement of competencies, and the results of MPBH implementation. Apart from analyzing the effectiveness of the MPBH, they will find out the obstacles that have arisen during their social history lectures by using the MPBH.

\section{RESULTS AND DISCUSSION}

The Historical Thinking Learning Model (MPBH) in the social history subject matter of mandai as a savior food in Banjarmasin society can be said to be effective after going through field testing. MPBH can increase the understanding of historical thinking of students of the History Education Study Program, FKIP, University of Lambung Mangkurat.Based on the results of observations, interviews and evaluations, it was found that there was a significant increase in knowledge, attitudes and skills. So that MPBH is effective enough for the achievement of learning objectives and social history competencies. Of course, if the support for infrastructure, learning resources, and subjective support in MPBH is fulfilled.Here are some test results that show the effectiveness of MPBH.

\subsection{Student Motivation in Learning with MPBH}

Motivation is a force that encourages or moves individuals to carry out activities to achieve a goal [23]. More specifically, Nawawi [24] differentiates it into two types, namely intrinsic motivation (impulses that come from within oneself) and extrinsic motivation (impulses that come from outside oneself).At certain levels of behavior, motivation greatly influences learning outcomes. Therefore, individual motivation is usually influenced by two things, namely the tendency to achieve success and the tendency to avoid failure.

Building student motivation for the development of MPBH in the Social History course begins with a dialogue with several students about the culture and culinary of the people of Banjarmasin, namely mandai. At the beginning of the even semester that had just passed, students participating in the Social History course were given an explanation of the MPBH learning and lecture contracts. The results of the interviews with students on the one to one evaluation and the small group evaluation, students stated and felt an interesting learning atmosphere and made them motivated to think historically through MPBH.

\subsection{Student Response in Using MPBH}

In the implementation of MPBH in the Social History course, the subject of mandai as a savior food in Banjarmasin society, it is known that student responses show interest. This is confirmed by the results of observations made at every meeting, where the student's response to the MPBH shows an increase in interest. In addition, interviews were also conducted with students who were divided into 3 different periods for 1 year. Based on the results of the interview, there were differences in student responses between the 1st period, 2nd period, and 3rd period, namely there was an increase. This increase is a sign that MPBH can increase student responses to the topics 
given. If the response increases, it can also be interpreted that students' interest in MPBH increases. The results of research on student responses to MPBH are also relevant to what Anis has done (2019) in different subjects with different methods. In this case the previous researchers used quantitative methods, the result was that the average student response for the whole group was 68.54 with the lowest score being 50 and the highest being 79 . The median score (after being sorted) was 69. Asymp value. Sig from Chi Square statistic $(\mathrm{df}=2)$ is $0.000<\alpha 0.05$ so that means rejecting $\mathrm{Ho}$ and accepting $\mathrm{Ha}$. This means that student responses have also increased. 54 with the lowest score is 50 and the highest is 79 . The median score (after sorted) is 69. Asymp value. Sig from Chi Square statistic $(\mathrm{df}=2)$ is $0.000<\alpha 0.05$ so that means rejecting Ho and accepting Ha. This means that student responses have also increased. 54 with the lowest score is 50 and the highest is 79 . The median score (after sorted) is 69. Asymp value. Sig from Chi Square statistic $(\mathrm{df}=2)$ is $0.000<\alpha 0.05$ so that means rejecting Ho and accepting Ha. This means that student responses have also increased.

\subsection{Development of Student Knowledge}

The learning process should result in an advancement of thought or development of knowledge. The addition of knowledge needed by students is about how to interpret facts in Social History. Interpreting historical facts is done by combining contextual historical phenomena with theories [25]. In this case, students are emphasized to be able to see historical phenomena from their own point of view, then are allowed to be able to relate past events with current phenomena. This is an important component in the $\mathrm{MPBH}$.

\subsection{Achievement of Student Competencies}

The idea of MPBH is felt to be able to deconstruct an understanding of historical studies from a contemporary perspective. MPBH is certainly different from conventional history learning which is dominated by memorization. The difference is marked by making it easier for students to obtain historical, critical information, and helping students to become skilled in participating in the MPBH. It is hoped that with MPBH students in learning history are always critical, so that they are able to present historical narratives that are humane, plural, and able to explain current realities.

Table 1 Achievement of Social History Competencies of the Subject of Mandai as a Rescue Food in Banjarmasin Society

\begin{tabular}{|l|l|l|l|}
\hline \multicolumn{1}{|c|}{ Competence } & \multicolumn{1}{|c|}{ Basic competencies } & Approach & $\begin{array}{l}\text { Achievement of Results } \\
\text { Student Participants of } \\
\text { the } \begin{array}{l}\text { MPBH Social } \\
\text { History }\end{array}\end{array}$ \\
\hline $\begin{array}{l}\text { Students understand, } \\
\text { analyze and evaluate the } \\
\text { subject matter of mandai as } \\
\text { a savior food in } \\
\text { Banjarmasin society. }\end{array}$ & $\begin{array}{l}\text { Able to understand, analyze } \\
\text { and evaluate the subject } \\
\text { matter of mandai as a savior } \\
\text { food in Banjarmasin society. }\end{array}$ & $\begin{array}{l}\text { Individual competency } \\
\text { assessment }\end{array}$ & $\begin{array}{l}\text { There was an increase in } \\
\text { the student's average } \\
\text { score from pre-test to } \\
\text { post-test, from 72.72 to } \\
78.44 .\end{array}$ \\
\hline $\begin{array}{l}\text { Attributes of critical } \\
\text { thinking }\end{array}$ & $\begin{array}{l}\text { Able to respond and present } \\
\text { historical facts about "mandai } \\
\text { as a savior food in } \\
\text { Banjarmasin society" }\end{array}$ & $\begin{array}{l}\text { Group competency } \\
\text { assessment }\end{array}$ & $\begin{array}{l}\text { The results of the group } \\
\text { assessment by the } \\
\text { obeserver: } \\
\text { Group } 1 \text { is } 78.75 \\
\text { Group 2 is } 80 \\
\text { Group 3 is } 82.5 \text { Group } 4 \\
\text { is 83.75 } \\
\text { Group 5 is } 85 \\
\text { Group } 6 \text { is } 85\end{array}$ \\
\hline Interactive skill attributes. & $\begin{array}{l}\text { Able to communicate } \\
\text { historical facts "mandai as a } \\
\text { savior food in Banjarmasin } \\
\text { society" in an open forum }\end{array}$ & & \\
\hline
\end{tabular}

Thus, Competence as a learning goal is generally achieved

\subsection{Changes in Student Academic Culture in Learning}

Academic culture will influence student academic behavior, while culture is shaped by the environment. At first, students were still used to being passive participants in lectures, did not prepare themselves for college, and lacked reading. So that it is rather difficult to express ideas, is not critical and is not able to connect current problems with historical problems. The atmosphere became fluid when presented the subject of mandai as a savior food in Banjarmasin society. Given that the subject matter is localized and actual, it is actually close to memory and the environment so that they feel close to the issue being discussed. This phenomenon suggests that problem solving faced by students is able to spark emotions to solve problems in the learning process [22]. Likewise, the Social History lecturers who are able to act as facilitators and are able to create dynamic classes. Seeing this phenomenon, the MPBH which has been more refined, it seems that the effectiveness of this model can be used better.

\section{CONCLUSION}

Based on the results of the field, it can be concluded that the Historical Thinking Learning Model (MPBH) can improve 
the understanding of historical thinking of students of the History Education Study Program FKIP, Lambung Mangkurat University which is implemented in the Social History course, especially on the subject of smart as a savior food in Banjarmasin society. MPBH effectively shows a significant increase in knowledge, attitudes and skills, of course as long as the support for infrastructure, learning resources, and subjective support in MPBH is fulfilled.

\section{REFERENCES}

[1] S. F. Nisa', J. Sayono, and I. W. P. Utami, "Pembelajaran Sejarah Indonesia Di Sman 1 Malang Dalam Mengembangkan Kemampuan Berpikir Historis," J. Pendidik. Sej. Indones., vol. 2, no. 2, pp. 202-211, 2019, doi: 10.17977/um033v2i22019p202.

[2] S. Heri, Seputar Pembelajaran Sejarah; Isu, Gagasan Dan Strategi Pembelajaran. Aswaja Pressindo, 2014.

[3] M. Z. A. Anis, "Model Pembelajran Berfikir Historis dan Sistem Evaluasinya untuk Mata Kuliah Metode Sejarah Pada Program Studi Pendidikan Sejarah FKIP Universitas Lambung Mangkurat," Universitas Negeri Jakarta, 2019.

[4] M. Subiyakto, B., \& Mutiani, "INTERNALISASI NILAI PENDIDIKAN MELALUI AKTIVITAS MASYARAKAT SEBAGAI SUMBER BELAJAR ILMU PENGETAHUAN SOSIAL," Khazanah J. Stud. Islam dan Hum., vol. 17, no. 1, pp. 137-166, 2019.

[5] T. Hartoto, "Model Pembelajaran Kooperatif Tipe Group Investigation (Gi) Meningkatkan Aktivitas Dan Hasil Belajar Sejarah," Historia Santiago., vol. 4, no. 2, p. 131, 2016, doi: 10.24127/hj.v4i2.553.

[6] B. Garvey and M. Krug, Model-Model Pembelajaran Sejarah Di Sekolah Menengah. Yogyakarta: Ombak, 2017.

[7] P. Seixas, "A Model of Historical Thinking," Educ. Philos. Theory, vol. 49, no. 6, pp. 593-605, 2017, doi: 10.1080/00131857.2015.1101363.

[8] J. Sayono, "Pembelajaran Sejarah Di Sekolah: Dari Pragmatis Ke Idealis," J. Sej. Dan Budaya, vol. 7, no. 1, pp. 9-17, 2013, [Online]. Available: http://journal.unnes.ac.id/sju/index.php/ijhe\%0A PENGARUH.

[9] Isjoni, Pembelajaran Sejarah Pada Satuan Pendidikan. Bandung: Alfabeta, 2007.

[10] I. Purnamasari and Wasino, "Pengembangan Model Pembelajaran Sejarah Berbasis Kabupaten Temanggung," J. Paramita, vol. Vol. 21, no. No. 2, pp. 202-212, 2011.

[11] F. Apomfires, "Makanan Pada Komuniti Adat Jae: Catatan Sepintas-Lalu Dalam Penelitian Gizi," Antropol. Papua, vol. 1, no. 2, pp. 1-9, 2002.
[12] Y. Nurti, "KAJIAN MAKANAN DALAM PERSPEKTIF ANTRPOLOGI," J. Antropol. IsuIsu Sos. Budaya, vol. 19, no. 1, pp. 1-10, 2017.

[13] A. Rahmadi, "Profil Perubahan Populasi BAL, $\mathrm{pH}$, Kadar Flavonoid, dan Potensi Aktivitas Antioksidan dari Fermentasi Mandai Cempedak Higienis Tanpa Garam. Bandar Lampung,” 2017.

[14] Y. Mulyani and D. N. Ulfiana, "PEMANFAATAN OLAHAN KULIT BUAH CEMPEDEAK (MANDAI) MENJADI SERUNDENG," Pros. Semin. Balai Ris. dan Standarlisasi Ind. Samarainda, 2017.

[15] L. M. and J. L. P. Westhaft, "Developing Preservice Teachers' Pedagogical Content Knowledge about Historical Thinking," Int. J. Soc. Educ., vol. 22, no. 2, pp. 1-28, 2008, [Online]. Available: https://files.eric.ed.gov/fulltext/EJ818470.pdf.

[16] Y. Sofiani, O. Agus, and K. Shavab, "Kontribusi Model Pembelajaran Kooperatif Learning Tipe Group Investigation Berbantuan Learning Management System (LMS) Berbasis Edmodo dalam Meningkatkan Kemampuan Berpikir Historis Mahasiswa Calon Guru Sejarah," Indones. J. Hist. Educ., vol. 6, no. 2, pp. 115-122, 2018.

[17] I. H. Alwahid, S. Sarkadi, and U. Umasih, "PENGARUH METODE PEMBELAJARAN COPERATIVE SCRIPT DAN KEMAMPUAN BERPIKIR HISTORIS TERHADAP HASIL BELAJAR SEJARAH SMA NEGERI 2 KOTO XI TARUSAN KABUPATEN PESISIR SELATAN PROVINSI SUMATERA BARAT," J. Imiah Pendidik. dan Pembelajaran, vol. 2, no. 2, 2018, doi: 10.23887/jipp.v2i2.14509.

[18] M. H. Hergenhahn, B.R dan Olson, Theories of Learning. Jakarta: Kencana Prenada Median Group, 2009.

[19] A. Auliani, O. Ofianto, and A. Aisiah, "Pengembangan Instrumen Pengukuran Kemampuan Berpikir Kausalitas Peserta Didik pada Mata Pelajaran Sejarah SMA,” J. Halaqah, vol. 1 , no. 1, pp. 67-78, 2019.

[20] E. Nugraheni and N. Pangaribuan, "Gaya Belajar Dan Strategi Belajara Mahasiswa Jarak Jauh: Kasus Di Universitas Terbuka," J. Pendidik. Terbuka dan Jarak Jauh, vol. 7, no. 1, pp. 68-82, 2006.

[21] R. P. Jatmiko, "Status sosial ekonomi, gaya, dan prestasi belajar," J. Penelit. dan Pendidik. IPS, vol. 11, no. 1, pp. 38-53, 2017.

[22] D. Samuel, "Pengaruh Budaya Belajar, Strategi Pengajaran Dosen, Dan Motivasi Belajar Terhadap Hasil Belajar Mahasiswa Pendidikan Ekonomi Fkip Uksw,” J. Educ. Soc. Stud., vol. 3, no. $2,2014$. 
[23] N. S. Sukmadinata, Landasan Psikologi Proses Pendidikan. Bandung: Aswaja Pressindo, 2005.

[24] Nawawi, Manajemen Sumber Daya Manusia. Yogyakarta: Gadjah Mada University Press, 1987.
[25] D. Booth, "Evidence revisited: Interpreting historical materials in sport history," Rethink. Hist., vol. 9, no. 4, pp. 459-483, 2005, doi: $10.1080 / 13642520500307990$. 